\title{
Education and sustainable national development in Nigeria: challenges and way forward
}

\author{
Abubakar Aminu Boyi \\ Shehu Shagari College of Education, Sokoto, Nigeria \\ E-mail address: abubakaraminu026@gmail.com
}

\begin{abstract}
Education is an important key of achieving a sustainable national development. For a state or society to achieve a sustainable national development, the quality of its education should be improved. This paper attempts to explain the concept of education, the concept of sustainable national development and relationship between education and sustainable national development. The paper provides an insight into various challenges confronting education in Nigeria such as gender inequity in education, dearth of teachers, inadequate infrastructures, overcrowded classrooms etc. It finally suggested way on how to solve challenges confronting education in Nigeria. This is done through creation of conducive atmosphere for learning, allocation of enough funds for educational development, discouraging gender disparity in education by an enlightenment programme, setting up a trustworthy committee that will manage and supervise education etc.
\end{abstract}

Keywords: Education; Sustainable Development; Gender Inequality; Infrastructure; Change

\section{INTRODUCTION}

Education at all levels and in all its forms constitutes a vital tool for addressing virtually all global problems. Education is not only an end in itself. It is a key instrument for bringing about changes in knowledge, values and behaviours and life styles required to achieve sustainability and stability within and among countries (Bajaj and Chiv, 2009:9).

Education has been seen as the greatest force that can be used to bring about changes. Aminu (1995), observed that the greatest investment a nation can make for the development of its economic, sociological and human resources is that of education. Education according to him provides us with people possessing the necessary knowledge and skills to win a nation's state and to even export brains. This also explains why the Federal Government of Nigeria geared a policy towards attaining national development. According to National Policy on Education (2004:8).

Education shall continue to be highly rated in the national development plans because education is the most important instrument for change: any fundamental change in the intellectual and social outlook of any society has to be preceded by an education revolution. 
The above statement shows that education is an important instrument for change and national development. Against this background, this paper presents a discussion on the challenges confronting education as an agent of sustainable national development in Nigeria and the way forward.

\section{CONCEPT OF EDUCATION}

Education has been conceptualized in various ways by scholars. Education is seen as the light that derives away the darkness of ignorance and enables mankind to find its ways through the tortures and labyrinth of development and civilization (Ikechukwu, 2006).

According to UNESCO (2000), "education refers to the total process of developing human ability and behaviours". It is an organized and sustained instruction designed to communicate a combination of knowledge, skills and understanding value for all activities of life.

Education refers to what can be used by man to solve his problems to improve his life and make it comfortable. It is one of the several ways that man employs to bring change in to his all round development. Education demands efforts and discipline. It is also a formidable tool for man's survival.

Ayu (1991), conceived education as "what brings about the moral development and spiritual upliftment of the human personality and of the community as a whole". He stressed further that education makes mankind more creative and enables him to live a more fulfilling life through interaction.

Peter (1966:6), identified three central criteria that are explicit to the concept of education which are:

* That education implies the transmission of what is worthwhile to those who become committed to it;

* That education at least rules out some procedures of transmission on the ground that they lack wittingness and voluntariness on the part of the learner;

* That education must involve knowledge and understanding and some kind of cognitive perspectives which are not inert.

Fafunwa (1994) however, defined education as "the aggregate of all the processes by which a child or young adult develops abilities, attitudes and other forms of behaviours which are of positive value to the society in which he lives". He stressed further that education is a process of transmitting culture in terms of continuity and growth and for disseminating knowledge to ensure social control or guarantee rational direction of society both.

Education has been defined as a systematic procedure for the transfer and transformation of culture through formal and informal training of people in a society; it deals with mental, physical, psychological and social development of citizens in a given society (Ebong in Eghure, 2007).

Holborn and Haralambos (2004), see education as an institution that enables individual to think freely and rationally which makes social progress and innovation possible. Social progress and innovation are the key elements of development, when a society progresses, its members are free; they think rationally, innovate certain social changes which will invariably enhance development. From the foregoing, therefore, it can be perceived that education is an instrument or tool for achieving national development. 


\section{THE CONCEPT OF SUSTAINABLE NATIONAL DEVELOPMENT}

Previously, the attention was basically on the concept "Development". However, the Bruntland Commission shifted the attention by reshaping and modifying the concept to "Sustainable Development."

The most interesting aspect of sustainable development is the fact that it puts in to consideration the present conditions of people as well as not compromising those that come later. Therefore, the concept of sustainable national Development remains the modern parameter of measuring development.

The Bruntland Commission, (1987) defined sustainable Development as "the development that meets the needs of the present without compromising the ability of the future generations to meet their own needs."

In another definition by Munasinghe (2004), sustainable national Development is a process of improving the range of opportunities that will enable individual humans and communities to achieve their aspirations and full potential over a sustained period of time while maintaining the resilience of economic, social and environmental systems.

Age (2005:85), identified some objectives which sustainable national development is expected to realize: increase capital income and employment, promoting human welfare satisfying basic needs; protecting the environment.

Considering the path of future generation, achieving equity between rich and poor and participation on a broad basis in development and decision making is important.

From the above definitions, there are common phenomenona which they all shared; that is prioritizing the development of the present generation without compromising the future generation.

\section{EDUCATION AND SUSTAINABLE NATIONAL DEVELOPMENT: THE RELATIONSHIP}

Having stated above, the various definitions of education and sustainable national development, it is imperative to examine the relationship between the two concepts.

In all nations, Nigeria inclusive, education remains the instrument for effective national development. Development is championed through education, which is often assumed to have significant influence. Education entails the enlightenment of people in their ways of pursuit in life. Development is associated with a positive change in the condition of either individual groups, communities or even a country as a whole (Umoh, 2005:224).

Education and sustainable national development are interwoven, intertwined, and interconnected. While on the one hand, development is geared towards producing or creating something new or more advanced for the society and its members. On the other hand, education is a tool which can enhance the desired sustainable development. Umoh, 2005 therefore, refers education and sustainable development as two sides of the same coin.

The fact that education and sustainable development shows glaring connectivity probably explained why scholars emphasized the need for education for the purpose of achieving the desired sustainable development.

Ebong (1996:6), sees education as a systematic procedure for the transfer and transformation of culture through formal and informal training of people in the society. He stated that education deals with mental, physical, psychological and social development of the citizens in a given society. He further stated that "the goal of education in man power 
development is aimed at national growth and development" (Ebong 1996:6). For any country therefore, to attain sustainable national development, he concluded that "there is need for skilled man power and those skills required are basic ingredients for national development and can only be acquired through education" (Ebong 1996:6).

Education provides consciousness, awareness and enlightenment to individuals in order to properly pursue their aspirations and yearnings.

It is also mentioned by Olubadewo (2006:9) that it is only educated population that can command skills necessary for sustainable economic growth and a better quality of life.

Sustainable national development may therefore be seen as the target goal since it is meant for the society and its members; education however remains the instrument for achieving and attaining the target goal.

From the above, education seems to directly determine wether sustainable national development is going to be achieved or not and therefore, the need for a well structured educational system that will enhance the achievement of the aforementioned development.

\section{CHALLENGES OF EDUCATION IN NIGERIA}

The fact is education constitutes the major instrument for sustainable human development and fulcrum around which every other activity revolves (Tahir, 2006:21) Nation which have recorded tremendous feats in the world heavily relied on the instrumentality of education.

However, in Nigeria there seems to be a daily decline of educational standards. Although according to the former president Olusegun Obasanjo in his Presidential Speech on April, 24, 2000 in Dakar Senegal, he attributed the educational falling standard to bad governance. In his speech; he stated that:

Nigerian educational system as it stands is a living proof of the damages that bad governance can do to our society and social structure.

Human beings are the architects and engineers of progressive change and development and they constitute the most important resource we can have internally.

Tahir (2006), identified a number of daunting challenges which Nigerian education is confronted with. They are as follows:

i. Gender equity in education;

ii. Dearth of teachers;

iii. Overcrowded classrooms;

iv. Inadequate infrastructures;

v. Funding of education.

i. Gender Equity in Education: Gender disparity is a well known feature of Nigerian educational landscape. Educational policies and practices in Nigeria are to say the least gender insensitive and thus not fashioned to achieve gender balance in schools.

\section{Gender Equity}


Table 1. Nigeria - Regional and Gender Differences in Literacy Rates in 2010.

\begin{tabular}{|c|c|c|}
\hline ZONE & WOMEN & MEN \\
\hline South East & $65 \%$ & $75 \%$ \\
\hline South West & $55 \%$ & $80 \%$ \\
\hline North West & $30 \%$ & $40 \%$ \\
\hline North East & $25 \%$ & $41 \%$ \\
\hline
\end{tabular}

Source: Unicef 2010

The table above shows the Nigeria- Regional and Gender differences in literacy rates in 2010. The table also shows that there is a disparity in literacy rates between men and women in some parts of the geo-political zones of Nigeria.

ii. Shortage of Teachers: It is a well known fact that no educational system in a nation can rise above the quality of its teachers. In other words, the success of the system rests on the availability of good and qualified teachers who are internally motivated. Wasagu, (2006) stated that "Teachers are the way to improvement since they are the final brokers when it comes to educational policy". Former minister of Education, Professor Ruqayyatu Rufai (2010) stated that "lack of Qualified teachers was responsible for the dismal performance of students especially in mathematics and English language". That poor performance turned out to be a child's play when NECO released its own SSCE results which showed that only 126,500 of the 1,260,765 candidates, just 10 percent of those who registered for the body's exams passed five subjects including English and mathematics. The statistics also showed that only about 234,682 out of the 1,260,765 candidates who sat for the exams made five credits in five core subjects the minimum requirements for the university admission in Nigeria. That means only two percent passed the exams with five credits including English and mathematics. Therefore where there are competent, capable and well motivated personnel among other things, the educational system of a country can surely succeed.

iii. Over crowding: The introduction of UPE brought with a sudden population explosion in schools and its resultant effects on teacher-pupil or student ratio. Overcrowding in the classroom is now the order of the day from Primary to university level. Because of the overcrowded classrooms, there are usually not enough places for the number of students in class/lecture rooms. This type of atmosphere is not condusive for effective teaching/learning process. Effective teacher/student relationship may not be possible in an over crowded classroom. This probably explains why teachers in higher institutions of learning resort to the use of handouts (Akande, 2004:63).

iv. Inadequate infrasture: This refers to the physical and spatial enablers of teaching/ learning. They include classrooms, libraries, laboratories, workshops, play fields, school farms and gardens as well as provision of water and sanitation. These have to be of the appropriate quantity, size and quality to meet the minimum standards for promoting any meaningful teaching and learning condition. 
v. Funding of Education: The managers of primary secondary and higher institutions in Nigeria are in consensus that these institutions are grossly under funded. This menace could be seen in the degree of dilapidation that characterizes the primary and secondary buildings in parts of the country. The non-payment of teachers' salaries and allowances which most times result in strikes. There is lack of necessary teaching and learning material at all levels of the educational system. Finally, the mismanagement and diverting of substantial resources from the educational system to other ends. The under funding has been criticized and attributed to several factors ranging from military rule, diversion and mismanagement of funds and lack of focus (Victor, 2002, Dike 1999, Bolag 2002).

\section{THE WAY FORWARD}

The following are some of the suggestions:

$\checkmark \quad$ There are needs for allocation of enough funds to various educational institutions;

$\checkmark \quad$ There are need for a committee managing and supervising projects to ensure implementation of project design for a particular developmental programme in schools;

$\checkmark \quad$ For the purpose of achieving sustainable national development, there are needs for learning under a condusive environment. As such, the dilapidated infrastructural facilities in schools and colleges must be improved;

$\checkmark \quad$ Teachers who are to disseminate knowledge must be properly motivated to give and put in their best. As such the need for salary increment and better working conditions;

$\checkmark \quad$ Government at all levels Federal, state and local must contribute their respective quota to the development of education. This will ensure a speedy achievement of sustainable national development.

$\checkmark \quad$ Gender disparity and boys and girls drop out should be discouraged by a particular enlightenment programme using media (such as radio, television, etc.)

\section{CONCLUSION}

Education is the cornerstone of achieving a sustainable national development. There are no doubts achieving sustainable national development is the goal of all developing nations, Nigeria inclusive. As such there are the needs to invest, encourage and enlighten people on education. The roles of government at all levels are to facilitate the achievement of any development.

Government should continue the contribution towards achieving this sustainable development. However, the need for monitoring, supervising and ensuring that all the financial and other investment on education for the purpose of achieving sustainable development are not diverted for other purposes. 


\section{References}

[1] Age E. (2005). Objectives of Teaching Education In Nigeria. London, British Council.

[2] Akande (2006). "Issues and challenges In Nigerian Education In the $21^{\text {st }}$ century". Farfaru Journal, Volume 1.

[3] Aminu J. (2006). "Issues and challenges In Nigerian Education In the $21^{\text {st }}$ century". Farfaru Journal of Mutti-Disciplinary studies Vol. I. Sokoto.

[4] Ayu A., Farfaru Journal of Multi-Disciplinary studies 1-2 (1991) 235-243.

[5] Basic Education (2011). Available at: http/en. Wikipedia. Org/wiki/Basic Education. Retrieved on $12^{\text {th }}$ May, 2011.

[6] Bolag and Umoh (2002). Nigerian Universities: Start to Recover from years of Violence, Corruption and Neglect. The chronicle of the Higher Education, Lagos, Nigeria.

[7] Bruntland Commission, (1987). Development Report on Sustainable Development, Newyork.

[8] Bwala M. H., Koroma D. S. (2005). Towards Sustainable Development of Nigeria. Lagos, Nigeria CSS Book shops.

[9] Ebong E. (1996). Fundamentals of Technology and Vocational Education. Enugu Cheston.

[10] Fafunwa A. B. (1974). History of Education in Nigeria. London, George Allen and Unwin.

[11] Federal Government of Nigeria, (2004). National Policy on Education. $4^{\text {th }}$ Edition Lagos, Nigeria NERCD.

[12] Haralambos M., Holborn M. (2004). Sociology Themes and Perspectives. London: Harper Collins Publishers.

[13] Igbuzor O., State of Education in Nigeria. A key note address delivered at a round table organized by Civil Society Action coalition on Education for all on $3^{\text {rd }}$ July, 2006.

[14] Ikechukwu O. G., Farfaru Journal of multi-Disciplinary Studies (12) (2006) 235-243.

[15] Munasinghe S. (2004). Effective Instructions Through Dynamic Discipline. Ohio, Charles E. Merill.

[16] Nigerian Education (2011). Available at http:www.maps of world. Com/Nigeria Education Retrieved on $12^{\text {th }}$ May,2011.

[17] Obasanjo O. (2000). “A Speech In Dakar, Senegal”. Farfaru Journal Vol. I. June, 2006.

[18] Olubademo S. O. (2006). Contemporary Issues In Nigerian Education. Lagos CSS Bookshops.

[19] Oghuve E. P., Journal of social sciences 1(14) (2007)19-24.

[20] Other Educational Developments (2011). Available at http://www. Online Nigeria. Com/Education/? Blunbs 535. Retrieved or 12 ${ }^{\text {th }}$ May, 2011.

[21] Peter, R. (1966). The Organizational Climate of Schools. Chicago, University of Chicago Midwest Administration Centre. 
[22] Rufa'I R. (2000). Speech on "lack of qualified Teachers Responsible For Dismal Performance of Students". Daily Trust 22 ${ }^{\text {nd }}$, August, 2010.

[23] Rajaj and Chiv, (2009). Education for Sustainable Development As Peace Education. A Paper Presented at Peace History Society and Peace and Justice studies Association. Ibadan, Nigeria.

[24] UNESCO (2000). Nigerian Human Resource Development and civilization: Education and world Affairs, Newyork.

[25] Tahir G. (2001) Federal Government Intervention in U.B. E. form 1(1) 1-12 Kaduna, Nigeria.

[26] Victor D. (2002). The State of Education in Nigeria and the Health of the Nation. Zaria, Ahmadu Bello University Press.

[27] Wasagu M. A., “The Nigerian Educational System and Challenges of Today." Sokoto Farfaru Journal Vol.1 June, 2006. 